\title{
Activated charcoal application for the micropropagation of Cattleya crispata (Thunb.) Van den Berg
}

\author{
Denys Matheus Santana Costa SOUZA ${ }^{1}$, Sérgio Bruno FERNANDES1, Letícia Vaz MOLINARI ${ }^{1}$, \\ Maria Lopes Martins AVELAR ${ }^{1}$, Gilvano Ebling BRONDANI ${ }^{1 *}$ \\ ${ }^{1}$ Federal University of Lavras, Lavras, MG, Brazil. \\ *E-mail: gilvano.brondani@ufla.br \\ (ORCID: 0000-0003-4256-7163; 0000-0002-9214-2377; 0000-0002-2543-4628; 0000-0001-6790-685X; 0000-0001-8640-5719)
}

Recebido em 09/04/2021; Aceito em 31/08/2021; Publicado em 20/09/2021.

\begin{abstract}
Micropropagation is an alternative for the genetic conservation and propagation of endemic species from rupestrian grasslands, such as the orchid Cattleya crispata. The aim of the present study is to assess the influence of activated charcoal on the in vitro germination, multiplication and elongation phases of $C$. crispata. Seeds extracted from mature capsules were used for inoculation in the culture medium that was adopted to assess the effect of supplementation, or not, with activated charcoal. Data about germination speed, number of shoots per explant, length, vigor, oxidation and contamination (bacterial and/or fungal) were assessed through these phases. Based on the results obtained, the use of activated charcoal was efficient in the in vitro germination and multiplication phases of $C$. crispata, providing greater speed and percentage of germination, less contamination and oxidation of the tissues, greater number, length and vigor of shoots, being effective for the genetic conservation and production of plants of the species. Culture medium without the supplementation of activated charcoal provided the best results for the in vitro elongation, with greater length, vigor and less oxidation of shoots.
\end{abstract}

Keywords: antioxidant; orchid; propagation in vitro; rupestrian grasslands.

\section{Aplicação de carvão ativado para micropropagação de Cattleya crispata (Thunb.) Van den Berg}

\begin{abstract}
RESUMO: A micropropagação é uma alternativa para a conservação genética e propagação de espécies endêmicas do "Campo Rupestre Ferruginoso", como a orquídea Cattleya crispata. O objetivo do presente estudo é avaliar a influência do carvão ativado nas fases de germinação, multiplicação e alongamento in vitro de $C$. crispata. Sementes extraídas de cápsulas maduras foram utilizadas para inoculação no meio de cultura adotado para avaliar o efeito da suplementação, ou não, com carvão ativado. Dados sobre velocidade de germinação, número de brotos por explante, comprimento, vigor, oxidação e contaminação (bacteriana e / ou fúngica) foram avaliados por meio dessas fases. Com base nos resultados obtidos, o uso do carvão ativado foi eficiente nas fases de germinação e multiplicação in vitro de C. crispata, proporcionando maior velocidade e porcentagem de germinação, menor contaminação e oxidação dos tecidos, maior número, comprimento e vigor dos brotos, sendo eficaz para a conservação genética e produção de mudas da espécie. $O$ meio de cultura sem a suplementação de carvão ativado proporcionou os melhores resultados para o alongamento in vitro, com maior comprimento, vigor e menor oxidação dos brotos.

Palavras-chave: antioxidante; campos rupestres; orquídea; propagação in vitro.
\end{abstract}

\section{INTRODUCTION}

Orchidaceae is one of the biggest families belonging to division Angiospermae, which encompasses approximately 900 genera and 27,135 species (CHASE et al., 2015). Brazil houses one of the largest orchid floras in the world, and many of them are epiphytes and endemic; they are represented by 240 genera and 2,443 species $-1,634$ are endemic (BARROS et al., 2015). However, because they have high market value, these species face great extractivism in their natural habitat for commercial exploration purposes, which leads to the loss of many individuals (BARROS et al., 2015; ANUCHAI et al., 2017).

Cattleya includes more than 113 species distributed in South and Central America (BERKA et al., 2014); in Brazil, this genus is represented by 48 species of epiphyte plants whose geographical distribution covers all states in the country, except for Amapá and Piauí (BARROS et al., 2015). Among species belonging to this genus, Cattleya crispata (Thunb.) Van den Berg is an endemic species native to Minas Gerais State, mainly distributed in Serra de Ibitipoca (BARROS et al., 2015), which is part of rupestrian grassland formation (VAN DEN BERG, 2014).

Nevertheless, tissue culture technique has been helping to preserve these species, since they allow the management of a large number of individuals living in reduced spaces, under aseptic conditions (RIGHETO et al., 2012; VILLA et al., 2014; POOBATHY et al., 2019). Accordingly, micropropagation, from germination to the subsequent phases on in vitro culture, is an efficient propagation and 
conservation technique applied to the germplasm of orchid species (GOMES et al., 2015; HUNHOFF et al., 2018). However, the success of orchid in vitro propagation is influenced by many factors, such as plant genotype and culture medium composition (HUNHOFF et al., 2018; KIM et al., 2019).

The definition of an appropriate culture medium is a limiting factor for orchid micropropagation (KIM et al., 2019); therefore, it is essential for studies carried out in each in vitro cultivation phase of $C$. crispata. Activated charcoal is among the components that can be added to culture media in order to act as antioxidant and to promote the adsorption of auxins and cytokinins, plant exudates and toxic metabolites (ANUCHAI et al., 2017; CORBELLINI et al., 2020).

The development of specific micropropagation is a strategy to be taken into consideration given the need of genetically conserving and propagating the species $C$. crispata. Therefore, the aim of the study was to assess the effect of activated charcoal supplemented in the culture medium at the in vitro germination, multiplication and elongation phases.

\section{MATERIAL AND METHODS}

\subsection{Study site and experimental material}

The experiments were carried out for 270 days, at the Laboratory of In Vitro Culture of Forest Species of the Department of Forestry Sciences of Federal University of Lavras, Lavras - MG, Brazil. The material used to generate the explants resulted from seeds extracted from mature capsules of Cattleya crispata, which were provided by the Gerdau's Unidade de Pesquisa e Inovação em Campos Rupestres Ferruginosos (GERDAU Açominas S.A), located in Ouro Branco - MG, Brazil.

\subsection{In vitro germination}

Seeds were washed in running water and immersed in fungal solution with $2.4 \mathrm{~g} \mathrm{~L}^{-1}$ of Orthocide $500 \AA(50 \%$ Captan was used as active ingredient) for 15 minutes. Next, they were washed five times in autoclaved deionized water and immersed in $70 \%$ hydroalcoholic solution (v/v) for 20 seconds under constant stirring in horizontal laminar flow chamber. Subsequently, seeds were immersed in $2.0-2.5 \%$ $\mathrm{NaOCl}$ solution (v/v) Clarix ${ }^{\circledR}$, for 5 minutes (SOUZA et al., 2020). Finally, they were washed in deionized water and autoclaved five times; $50 \mathrm{mg}$ of seeds were inoculated in test tube $(25 \times 150 \mathrm{~mm})$ filled with $10 \mathrm{~mL}$ of culture medium under aseptic conditions.

MS (Murashige; Skoog, 1962) was the basic culture medium used in the experiment. It was added with $30 \mathrm{~g} \mathrm{~L}^{-1}$ of sucrose (Synth Ltda) and $6 \mathrm{~g} \mathrm{~L}^{-1}$ of agar (Merck S.A.). Culture medium $\mathrm{pH}$ was adjusted to $5.8 \pm 0.05$ prior to agar addition; its autoclaving was carried out at $127^{\circ} \mathrm{C}$ and pressure of $1.5 \mathrm{kgf} \mathrm{cm}^{-2}$, for 20 minutes.

Seeds were kept in growth room for 90 days at temperature of $24 \pm 1{ }^{\circ} \mathrm{C}$, 16-hour light photoperiod and irradiance of $40 \mu \mathrm{mol} \mathrm{m} \mathrm{m}^{-2} \mathrm{~s}^{-1}$ (which was quantified in radiometer LI-COR $\AA$, LI-250A Light Meter) under white cold fluorescent light bulb.

The experiment followed a completely randomized design and used MS culture medium added with $1 \mathrm{~g} \mathrm{~L}^{-1}$ of activated charcoal (W/AC) (Merck S.A.), or without it (Wout/AC), with 30 replications (50 $\mathrm{mg}$ of seeds per replication). Data about germination percentage were collected at 20,30, 40, 50 and 60 days. Information about percentage of contamination by fungi and bacteria, oxidation and non-responsive seeds were collected at 90 days of subculture.

\subsection{In vitro multiplication}

After seed germination in vitro at 90 days of subculture, three standardized seedings $(0.5 \mathrm{~cm}$ in length) were prepared and inoculated in glass flasks ( $250 \mathrm{~mL}$ capacity) filled with 50 $\mathrm{mL}$ of basic MS culture medium, which was supplemented with $30 \mathrm{~g} \mathrm{~L}^{-1}$ of sucrose, $6 \mathrm{~g} \mathrm{~L}^{-1}$ of agar, $0.5 \mathrm{mg} \mathrm{L}^{-1}$ of $6-$ benzylaminopurine (BAP - Sigma $\left.{ }^{\circledR}\right)$ and $0.05 \mathrm{mg} \mathrm{L}^{-1}$ of $\alpha-$ naphthalene acetic acid (NAA - Sigma $\left.{ }^{\circledR}\right)$. The explants were cultivated for 90 days and the subcultures were used to renew the culture medium every 30 days.

The in vitro multiplication experiment was installed based on a completely randomized design. Saline MS culture medium added with $1 \mathrm{~g} \mathrm{~L}^{-1}$ of activated charcoal (W/AC), and without it (Wout/AC), was used in the experiment, with 30 replications (3 explants per replication; 90 individuals, in total). The mean number of shoots per explant $(>0.5 \mathrm{~cm})$, shoots length $(>0.5 \mathrm{~cm})$, vigor and oxidation based on the scores' scale proposed by Souza et al. (2020) (Fig. 1 A-F) were assessed at 90 days of in vitro culture.

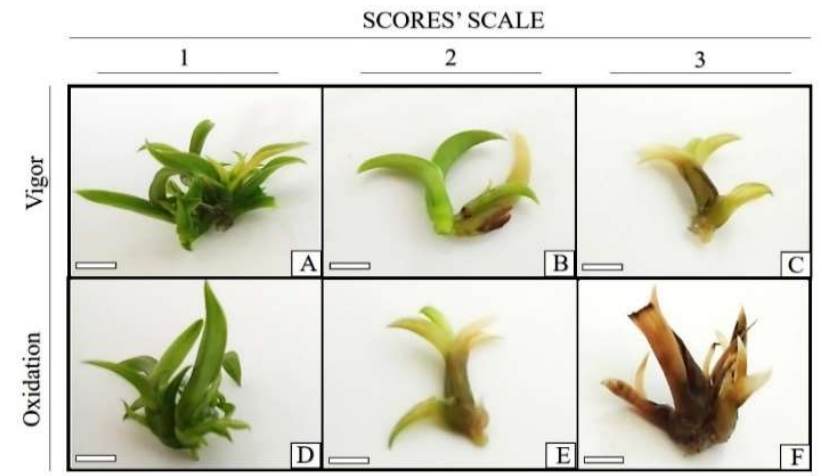

Figure 1. Vigor and oxidation assessments based on the scores' scale of tissues of C. crispata. A-C. Explant vigor ( $1=$ Excellent: shoot induction due to active growth, without apparent nutrition deficit; 2 $=$ Good: shoot induction, but with leaves presenting reduced size; 3 = low: no seedling induction and/or senescence and death). D-F. Explant oxidation $(1=$ Null: no oxidation; $2=$ Intermediate: reduced explant oxidation; $3=$ High: full explant oxidation). Bar $1 \mathrm{~cm}$.

\subsection{In vitro elongation}

Shoots generated in the multiplication phase in vitro at 90 days of culture were prepared as follows: three standardized seedlings $(0.5 \mathrm{~cm}$ in length) were inoculated in glass flasks (250 mL capacity). Each flask was added with $50 \mathrm{~mL}$ of MS culture medium, $30 \mathrm{~g} \mathrm{~L}^{-1}$ of sucrose, $6 \mathrm{~g} \mathrm{~L}^{-1}$ of agar, $0.05 \mathrm{mg}$ $\mathrm{L}^{-1}$ of BAP and $0.5 \mathrm{mg} \mathrm{L}^{-1}$ of indole-3-butyric acid (IBA Sigma $\left.{ }^{\circledR}\right)$. Explants were cultivated at 90 days and subcultures were used for culture medium removal every 30 days.

The in vitro elongation experiment followed a completely randomized design. It used saline MS culture medium added with $1 \mathrm{~g} \mathrm{~L}^{-1}$ of activated charcoal (W/AC), or without it (Wout/AC), with 30 replications (three explant per replication); thus totaling 90 individuals. The mean number of shoots per explant $(>0.5 \mathrm{~cm})$, shoots length $(>0.5 \mathrm{~cm})$, vigor and oxidation based on the scores' scale were assessed at 90 days of culture. 


\subsection{Data analysis}

Analyses were carried out in the R software, version 3.0.3 (R Core Team 2018), with the aid of package ExpDes, version 1.1.2 (FERREIRA et al., 2013). Variables that did not present normal distribution in the Shapiro-Wilk test, at 5\% significance level, were transformed into arcsen. Means recorded for the treatments were subjected to analysis of variance (ANOVA) through Tukey test, at 5\% significance level; the regression equations were adjusted.

\section{RESULTS}

\subsection{Activated charcoal in the in vitro germination}

The addition of activated charcoal to culture medium has influenced germination speed of orchid C. crispata, in vitro. Seeds subjected to the treatment with activated charcoal germinated 30 days after inoculation $(30 \%$ germination, on average); on the other hand, the treatment without activated charcoal recorded germination 40 days after inoculation (20\% germination, on average) (Fig. 2A).
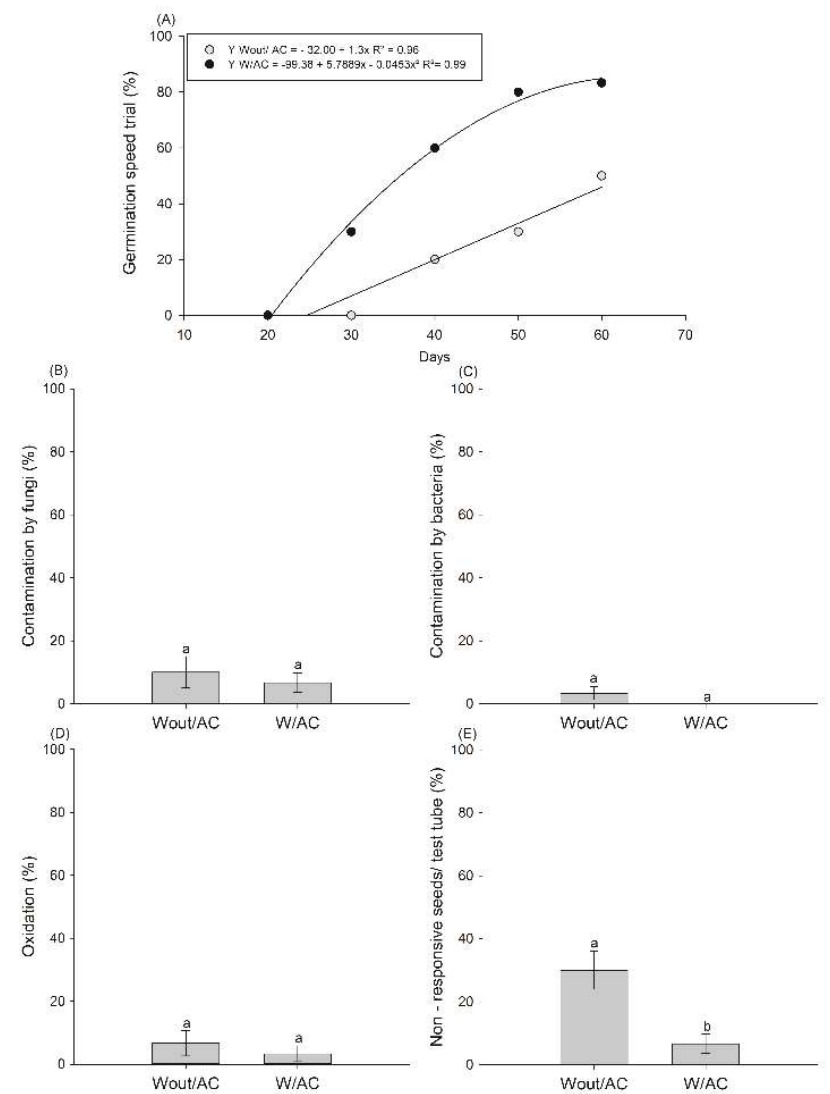

Figure 2. Features observed in the in vitro germination phase of $C$. crispata, with and without culture medium supplementation with activated charcoal. A. Germination speed at 20, 30, 40, 50 and 60 days; B. Fungal contamination percentage; C. Bacterial contamination percentage; D. Oxidation percentage; E. Percentage of non-responsive seeds. ${ }^{*}$ Means followed by the same letter did not differ from each other in the Tukey test at 5\% significance level. Bars represent the standard deviation of the sample.

The treatment with activated charcoal led to higher germination percentage at 60 days of culture $(83.3 \%$, on average), and this result was statistically different from the treatment without it (50\% germination, on average) (Fig. 2A). With respect to non-responsive seeds, the treatment without activated charcoal resulted in high mean for this variable
$(30 \%)$ and in statistical difference from the treatment without it $(6.6 \%$, on average) (Fig. $2 \mathrm{E})$.

There were similar components in the percentage of contamination by fungal and bacterial, and oxidation of tisses; the lowest means recorded for these variables were observed for treatments with activated charcoal (6.6, 0 and $3.3 \%$ ), but they did not differ from the treatment without activated charcoal (Figs 2B, 2C and 2D). The best results given the characteristics evaluated with the presence of activated charcoal, denote the potential of the antioxidant for the in vitro germination of $C$. crispata.

\subsection{Activated charcoal in the in vitro multiplication}

The effect of supplementation with activated charcoal, significantly inferred the morphological characteristics studied in the in vitro multiplication of $C$. crispata.

Supplementation with activated charcoal at 90 days of culture for in vitro multiplication of orchid C. crispata led to the largest number and longest length of shooting (5.0 shooting $-1.8 \mathrm{~cm}$, on average). This outcome was statistically different from the treatment without it (3.9 shooting - 1.3 $\mathrm{cm}$, on average) (Figs $3 \mathrm{~A}$ and $3 \mathrm{~B}$ ). The addition of activated charcoal to the culture medium increases the adsorption of substances that inhibit plant development, as well as minimizes the toxicity of plant growth regulators or of exogenous substances with harming effect, which contributed to greater explant in vitro growth.

According to the scores' scale, vigor and oxidation presented the lowest means (1.3) due to the addition of activated charcoal to the culture medium; therefore, there was no statistical difference from the treatment without activated charcoal (Figs. 3C and 3D). The number of buds per explant, vigor and oxidation are characteristics that stand out as a tool to evaluate the efficiency of the multiplication phase, demonstrating to be factors that exert great influence on in vitro cultivation.
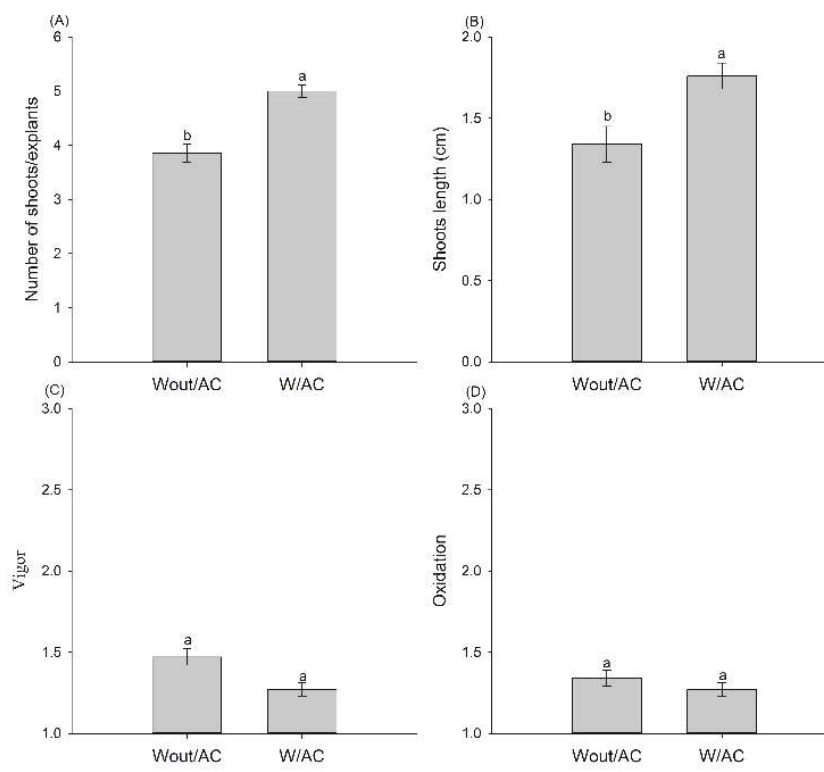

Figure 3. Features observed at 90 days of in vitro culture in the multiplication of $C$. crispata, with and without culture medium supplementation with activated charcoal. A. Number of shooting per explants; B. Shooting length; C. Vigor; D. Oxidation. *Means followed by the same letter did not differ from each other in the Tukey test at $5 \%$ significance level. Bars represent the standard deviation of the sample. 


\subsection{Activated charcoal in the in vitro elongation}

Based on the assessed features, was possible observing difference in the responses to treatment with, or without, culture medium supplementation with activated charcoal and in the growth pattern of C. crispata plants in the in vitro germination, multiplication and elongation phases at 90 days (Fig. 5).

The use of activated charcoal had direct influence on the in vitro elongation of $C$. crispata explants, it was determining for the largest number of shoots (3.3 shoots, on average) and for the shortest shoots length $(2.3 \mathrm{~cm}$, on average); therefore, there was statistical difference from treatments without activated charcoal supplementation (Figs. 4A and 4B). With the use of activated carbon at a concentration of $1 \mathrm{~g} \mathrm{~L}^{-1}$, inhibition of explant growth was observed in in vitro elongation, when compared to the system without antioxidant supplementation.

Vigor and oxidation assessments based on the scores' scale showed the lowest means without activated charcoal (1.3 and 1.3, on average) (Figs. 4C and 4D); however, there was no significant different from treatments without it. The treatment without the use of activated carbon provided the best results, being fundamental for the in vitro elongation phase, contradicting the aforementioned results of the in vitro germination and multiplication phases of C. crispata.
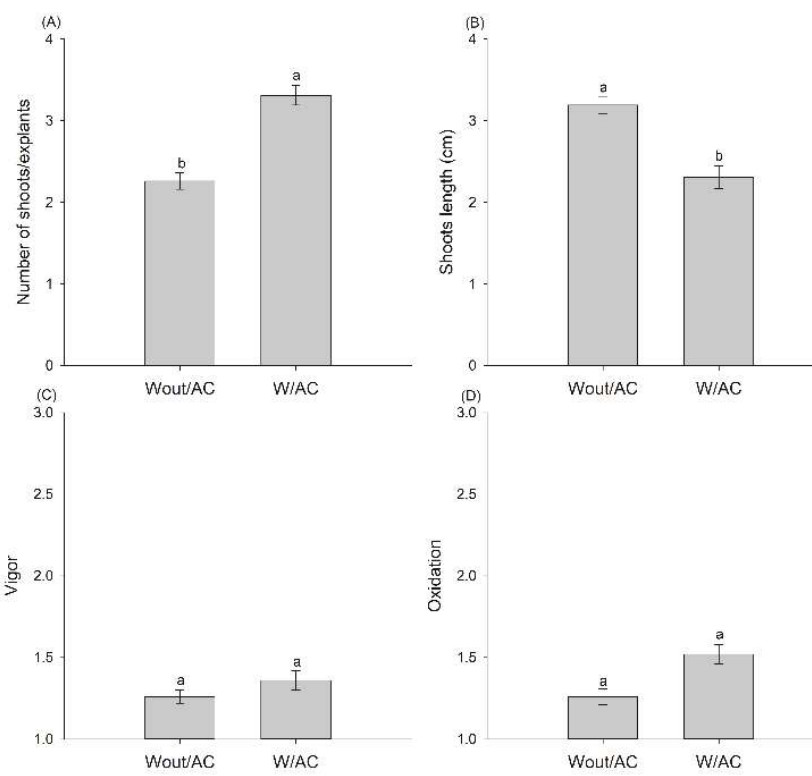

Figure 4. Features observed at 90 days of culture in the in vitro elongation of $C$. crispata, with or without culture medium supplementation with activated charcoal. A. Number of shoots per explant; B. Shoots length; C. Vigor; D. Oxidation. *Means followed by the same letter did not differ from each other in the Tukey test at $5 \%$ significance level. Bars represent the standard deviation of the sample.

\section{DISCUSSION}

\subsection{Activated charcoal in the in vitro germination}

The improvement of protocols for in vitro establishment that influences the development of micropropagation, were studied with the attempt to establish cultivation conditions that can maximize the production of clonal seedlings on a large scale. The results of the morphological characteristics evaluated with the orchid $C$. crispata, provided the optimization of the in vitro germination phase, through the use of activated charcoal.

The treatment with the use of activated charcoal provided the highest germination percentage at 60 days of cultivation and the lowest percentages of contamination, oxidation and unresponsive explants. These outcomes are similar to those found by Kim et al. (2019), who used $1 \mathrm{~g} \mathrm{~L}^{-1}$ of activated charcoal in the in vitro germination and regeneration of Pecteilis radiate. The addition of activated charcoal to the culture medium favored the maturation and germination of somatic embryos of Acrocomia aculeata (GRANJA et al., 2018), and it has pointed out the importance of culture medium supplementation with it.

The response of orchid seeds in in vitro germination is influenced by many factors, such as seed age, culture medium composition (carbohydrate source, antioxidants, plant growth regulators), culture condition and genotype (PARK et al., 2018; SEON et al., 2018). However, contamination by microorganisms (fungal and/or bacterial) is an issue associated with micropropagation, because these microorganisms establish themselves in the culture medium and/or in the vegetal material and cause toxicity due to the high production of toxic metabolites, as well as to $\mathrm{pH}$ reduction in the culture medium, which, consequently, leads to lower absorption of macro and micronutrients by plants and, unfortunately, to death (LEONE et al., 2016).

Data in the literature corroborated findings in the current study, since culture medium supplementation with $1 \mathrm{~g} \mathrm{~L}^{-1}$ of activated charcoal reduced oxidation and contamination in comparison to the treatment without it, during the micropropagation of Cattleya walkeriana (SOUZA et al., 2007) and Eugenia pyriformis (ASSIS et al., 2018). Futhermore, the germination and elongation phases, in vitro, also demand the control of oxidation caused by phenolic exudation in the region where explants are cut; oxidation was also responsible for explant darkening due to the activity of enzymes such as peroxidase and polyphenol oxidase (WILLADINO et al., 2013; CORBELLINI et al., 2020).

Activated charcoal acts as antioxidant and promotes the adsorption of plant exudates and toxic metabolites (HUNHOFF et al., 2018) due to the presence of a network of pores in the structure of activated charcoal, which allows many inhibitory substances in the medium, or released by the explants, to remain adsorbed (AGUILAR et al., 2016). Thus, the methodology used in the study with the supplementation of activated charcoal was observed the best results, providing greater development of explants, in which are important strategies to be adopted in the propagation system.

\subsection{Activated charcoal in the in vitro multiplication}

Supplementation with the activated charcoal significantly affected the morphological characteristics studied in in vitro multiplication, when compared without its supplementation. The use of antioxidants (polyvinylpyrrolidone - PVP and activated charcoal) allowed lower oxidation and greater development of Terminalia amazonia explants during micropropagation (MÉNDEZ et al., 2014). The use of activated charcoal in the intergeneric hybrid of orchid Brassocattleya pastoral $\times$ Laeliocattleya amber accounted for the largest number of shoots (VILLA et al., 2014).

The addition of activated charcoal to the culture medium increases the adsorption of substances - such as phenols and ethylene - that inhibit plant development, as well as minimizes the toxicity of plant growth regulators or of exogenous substances with harming effect, which contributes to greater shoots proliferation and explant in vitro growth (SARTOR et al., 2013; ABIRI et al., 2020), as observed in the present study. 
According to the scores' scale, vigor and oxidation presented the lowest means, due to the addition of activated charcoal to the culture medium. These results are close to the ones found by Souza et al. (2020), who observed low phenolic oxidation and good vigor in the explants of Corymbia citriodora $\times C$. torelliana in vitro cultivated. The use of antioxidants (PVP and activated charcoal) in Abelmoschus esculentus (IRSHAD et al., 2017), Psidium guajava (AGUILAR et al., 2016) and Lupinus mutabilis (MAMANI et al., 2014), explants reduced the effects of phenolic exudation and promoted better development in micropropagation.

\subsection{Activated charcoal in the in vitro elongation}

The supplementation of activated charcoal in in vitro elongation, showed different responses in relation to the germination and multiplication phases of $C$. crispata in vitro. Depending on the species, explant type or on the cultivation phase to be propagated, the addition of an antioxidant (activated charcoal and PVP) to the culture medium can have positive effects (PANKAJ et al., 2014), as observed in the in vitro culture of the species under study.

With respect to the negative effects of activated charcoal supplementation, it is possible highlighting the adsorption of growth regulators (auxins and cytokinins), vitamins and of other organic substances important for explant in vitro development and growth. Activated charcoal also naturally releases substances that are found on, or adsorbed by, it (ABIRI et al., 2020; CORBELLINI et al., 2020).

In vitro conditions are often stressing for plant growth and high concentrations of exogenous antioxidants can affect development during culture (TISARUM et al., 2018). Kim et al. (2019), report que culture medium supplementation with activated charcoal at concentration higher than $3 \%$ can promote and/or inhibit in vitro growth depending on the used species and tissues, as it was observed in the present study with the species of orchid C. crispata.

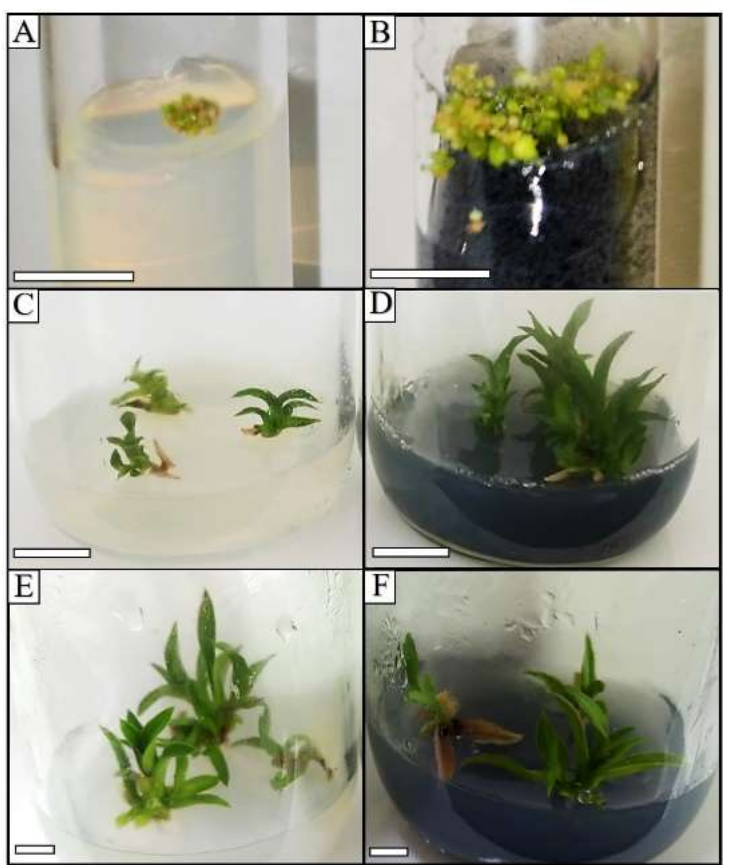

Figure 5. C. crispata explants subjected, or not, to the treatment with activated charcoal at 90 days after inoculation in each phase. A and B. In vitro germination; $\mathrm{C}$ and $\mathrm{D}$. In vitro multiplication; $\mathrm{E}$ and $\mathrm{F}$. In vitro elongation; A, C and E. without activated charcoal; B, D and F. with activated charcoal. $\mathrm{Bar}=1.0 \mathrm{~cm}$.

\section{CONCLUSIONS}

Supplementation of MS culture medium with activated charcoal recorded the best results for in vitro germination and multiplication of C. crispata.

Germination speed and percentage were higher under these conditions, there was lower contamination and tissue oxidation, as well as larger number, longer length and better vigor of explants.

The activated charcoal treatment was effective in the genetic conservation and production of plants belonging to this species. For the elongation phase, the MS culture medium without activated carbon showed the best results: longer shoots length, better vigor and less oxidation.

\section{ACKNOWLEDGEMNTS}

We thank the National Council for Scientific and Technological Development, Brazil (Conselho Nacional de Desenvolvimento Científico e Tecnológico - CNPq), Coordination for Improvement of Higher Education Personnel, Brazil (Coordenação de Aperfeiçoamento de Pessoal de Nível Superior - CAPES - Código de Financiamento 001), and Foundation for Research of the State of Minas Gerais, Brazil (Fundação de Amparo a Pesquisa do Estado de Minas Gerais - FAPEMIG). We also thank Gerdau's Unidade de Pesquisa e Inovação em Campos Rupestres (GERDAU Açominas S.A.) for the partnership in the execution of this study.

\section{REFERENCES}

ABIRI, R.; ATABAKI, N.; ABDUL-HAMID, H.; SANUSI, R.; SHUKOR, N. A. N.; SHAHARUDDIN, N. A.; AHMAD, S. A.; MALIK, R. The prospect of physiological events associated with the micropropagation of Eucalyptus sp. Forests, v. 11, n. 1, p. 1-29, 2020. https://doi.org/10.3390/f11111211

AGUILAR, L. P.; ESPINO, H. S.; MONTEIRO, L. L. V.; SEGOVIA, C. P.; BENÍTEZ, S. F. Propagación in vitro de guayaba (Psidium guajava L.) a partir de segmentos nodales. Revista Mexicana de Ciencias Agrícolas, v. 7, n. 2, p. 375-386, 2016.

ANUCHAI, V.; HSTEH, C. H. Effect of change in light quality on physiological transformation of in vitro Phalaenopsis 'Fortune Saltzman' seedlings during the growth period. The Horticultural Journal, v. 86, n. 3, p. 395-402, 2017. https://doi.org/10.2503/hortj.MI-151

ASSIS, F. A.; RODRIGUES, F. A.; PASQUAL, M.; ASSIS, G. A.; LUZ, J. M. Q.; JANONI, F.; COSTA, I. J. S.; COSTA, B. N. S.; SOARES, J. D. R. Antioxidants in the control of microorganism contamination and phenol oxidation in Eugenia pyriformis. Bioscience Journal, Uberlândia, v. 34, n. 1, p. 49-58, 2018. https://doi.org/10.14393/BJ-v34n1a2018-36311

BARROS, F.; VINHOS, F.; RODRIGUES, V. T.; BARBERENA, F. F. V. A.; FRAGA, C. N.; PESSOA, E. M.; FORSTER, W.; MENINI NETO, L.; FURTADO, S. G.; NARDY, C.; AZEVEDO, C. O.; GUIMARÃES, L. R. S. Orchidaceae na Lista de Espécies da Flora do Brasil. Jardim Botânico do Rio de Janeiro, 2015. Available from: http://www.floradobrasil.jbrj.gov.br

BERKA, M. G.; VENTURIERI, G. A.; TEIXEIRA, T. N. Development of Cattleya amethystoglossa $\times$ nobilior in simplified culture media. Acta Scientiarum. Agronomy, 
Maringá, v. 36, n. 4, p. 425-428, 2014. http://dx.doi.org/10.4025/actasciagron.v36i4.15492

CHASE, M. W.; CAMERON, K. M.; FREUDENSTEIN, J. V.; PRIDGEON, A. M.; SALAZAR, G.; VAN DEN BERG, C.; SCHUITEMAN, A. An update classification of Orchidaceae. Botanical Journal of the Linnean Society, v. 177, n. 2, p. 151-174, 2015. http://dx.doi.org/10.1590/2175-7860201869115

CORBELLINI, J. R.; RIBAS, L. L. F.; MAIA, F. R.; CORREIA, D. O.; NOSEDA, M. D.; SUZUKI, R. M.; AMANO, E. Effect of microalgae Messastrum gracile and Chlorella vulgaris on the in vitro propagation of orchid Cattleya labiate. Journal of Applied Phycology, v. 32, n. $\begin{array}{llll}1, & \text { p. } & 4013-4027, & \end{array}$ http:/ /dx.doi.org/10.1007/s10811-020-02251-9

FERREIRA, E. B.; CAVALCANTI, P. P.; NOGUEIRA, D. A. ExpDes: Experimental Designs Package. R packageversion 1.1.2, 2013.

GOMES, L. R. P.; FRANCESCHI, C. R. B.; RIBAS, L. L. F. Micropropagation of Brasilidium forbesii (Orchidaceae) through transverse and longitudinal thin cell layer culture. Acta Scientiarum. Biological Science, Maringá, v. 37, n. $2, \quad$ p. $143-149, \quad 2015$ https://doi.org/10.4025/ACTASCIBIOLSCI.V37I2.27 276

GRANJA, M. M. C.; MOTOIKE, S. Y.; ANDRADE, A. P. S.; CORREA, T. C.; PICOLI, E. A. T.; KUKIB, K. N. Explant origin and culture media factors drive the somatic embryogenesis response in Acrocomia aculeata (Jacq.) Lodd. ex Mart., an emerging oil crop in the tropics. Industrial Crops and Products, v. 117, p. 1-12, 2018. https://doi.org/10.1016/j.indcrop.2018.02.074

HUNHOFF, V. L.; LAGE, L. A.; PALÚ, E. G.; KRAUSE, W.; SILVA, C. A. Nutritional requirements for germination and in vitro development of three Orchidaceceae species in the southern Brazilian Amazon. Ornamental Horticulture, v. 24, n. 2, p. 87-94, 2018. http:/ /dx.doi.org/10.14295/oh.v24i2.1130

IRSHAD, M.; HE, B.; LIU, S.; MITRA, S.; DEBNATH, B.; LI, M.; RIZWAN, H. M.; QIU, D. In vitro regeneration of Abelmoschus esculentus L. cv. Wufu: influence of antibrowning additives on phenolic secretion and callus formation frequency in explants. Horticulture Environment and Biotechnology, v. 58, p. 503-513, 2017. https://doi.org/10.1007/s13580-017-0301-3

LEONE, G. F.; ALMEIDA, C. V.; ABREU-TAZARI, M. F.; BATAGNIN-PIOTTO, K. D.; ARTIOLI, F. A, C.; ALMEIDA, M. Antibioticoterapia em microplantas de abacaxizeiro (Ananas comosus). Ciência Rural, v. 46, n. 1, p. 89-94, 2016. https://doi.org/10.1590/01038478 cr20130958

KIM, D. H.; KANG, K. W.; ENKHTAIVAN, G.; JAN, U.; SIVANESAN, I. Impact of activated charcoal, culture medium strength and thidiazuron on non-symbiotic in vitro seed germination of Pecteilis radiate (Thunb.) Raf. South African Journal of Botany, v. 124, n. 1, p. 144 150, 2019. https://doi.org/10.1016/j.sajb.2019.04.015

MAMANI, I.; AVERANGA, K.; ESPINOZA, B.; TERRAZAS, E. Establecimiento del sistema de generación in vitro de callos de Lupinus mutabilis Sweet (Tarwi) a partir de hipocótilos. Revista de Ciencias Farmacéuticas y Bioquímicas, v. 2, n. 1, p. 25-36, 2014.

MÉNDEZ-ÁLVAREZ，D.; ABDELNOUR-ESQUIVEL, A. Establecimiento in vitro de Terminalia amazonia (Gmel.)
Excell. Revista Florestal Mesoamericana Kurú, v. 11, n. 27, p. 07-21, 2014. https://doi.org/10.18845/rfmk.v11i27.1774

MURASHIGE, T.; SKOOG, F. A revised medium for rapid growth and bioassays with tobacco tissue cultures. Physiologia Plantarum, v. 15, n. 3, p. 473-497, 1962. https://doi.org/10.1111/j.1399-3054.1962.tb08052.x

PANKAJ, K.; PANDEY, S.; ROY, K. Ascorbic and citric acids in combination resolve the problems encountered in micro-propagation of litchi from shoot tips. Cell and Tissue Research, v. 14, n. 1, p. 41-59, 2014.

PARK, H. Y.; KANG, K. W.; KIM, D. H.; SIVANESAN, I. In vitro propagation of Cymbidium goeringii Reichenbach fil. through direct adventitious shoot regeneration. Physiology and Molecular Biology of Plants, v. 24, n. 1, p. 307-313, 2018. https://doi.org/10.1007/s12298017-0503-2

RIGHETO, M. V. L.; ALMEIDA, L. V.; BRONDANI, G. E.; AMARAL, A. F. C.; ALMEIDA, M. Morfofisiologia de plântulas de Cattleya labiata Lindley e Cattleya eldorado Linden cultivadas in vitro sob influência de paclobutrazol. Revista Brasileira de Biociências, v. 10, n. 1, p. 20-25, 2012.

SARTOR, F. R.; ZANOTTI, R. F.; PÔSSA, K. F.; PILON, A. M.; FUKUSHIMA, C. H. Diferentes meios de cultura e antioxidantes no estabelecimento in vitro do jacarandá da Bahia. Bioscience Journal, v. 29, n. 2, p. 408-411, 2013.

SEON, K. M.; KIM, D. H.; KANG, K. W.; SIVANESAN, I. Highly competent in vitro propagation of Thrixspermum japonicum (Miq.) Rchb.f., a rare epiphytic orchid. In Vitro Cellular \& Developmental Biology - Plant, v. 54, n. 1, p. 302-308, 2018. https://doi.org/10.1007/s11627-0189890-5

SOUZA, G. C.; CLEMENTE, P. L.; ISAAC, V. L. R.; FARIA, S. P.; CAMPOS, M. R. C. Contaminação microbiana na propagação in vitro de Cattleya walkeriana $\mathrm{e}$ Schomburgkia crispa. Revista Brasileira de Biociências, v. 5 , n. 1, p. 405-407, 2007.

SOUZA, D. M. S. C.; XAVIER, A.; MIRANDA, N. A; GALLO, R.; OTONI, W. C. Light quality, 6benzyladenine and number of subcultives for in vitro multiplication of hybrid clones of Corymbia. Scientia Forestalis, v. 48, n. 128, p. e3282, 2020. https://doi.org/10.18671/scifor.v48n128.03

TISARUM, R.; SAMPHUMPHUNG, T.; THEERAWITAYA, C.; PTOMMEE, W.; CHA, S. In vitro photoautotrophic acclimatization direct transplantation and ex vitro adaptation of rubber tree (Hevea brasiliensis). Plant Cell, Tissue and Organ Culture, v. 133, n. 2, p. 215-230, 2018. https://doi.org/10.1007/s11240-017-1374-5

VAN DEN BERG, C. Reaching a compromise between conflicting nuclear and plastid phylogenetic trees: a new classification for the genus Cattleya (Epidendreae; Epidendroideae; Orchidaceae). Phytotaxa, v. 186, n. 2, p. 75-86, 2014. http://dx.doi.org/10.11646/phytotaxa.186.2.2

VILLA, F.; PASQUAL, M. E SILVA, E. F. Micropropagação de híbridos de orquídeas em meio knudson com adição de vitaminas do meio MS, benzilaminopurina e carvão ativado. Semina: Ciências Agrárias, v. 35, n. 2, p. 683694, $2014 . \quad$ https://doi.org/10.5433/16790359.2014 v35n2p683 
WILLADINO, L.; SOUTO, N. F. C.; ULISSES, C.; PORTO, A. L. F.; CAMARA, T.; SILVA, M. M. A. Embryos and lateral buds culture of Tapeinochilos Ananassae (Hassk). K. Schum. International Journal of Sciences, v. 2, p. 19-25, 2013. 